in endeavouring to obtain, by fraudulent means, a diploma from the Royal College of Physicians of Edinburgh.

The solicitor of Mr. Organ having refused, in the terms of his letter previously read, to offer any answer to them, and having repeated the protest contained in that letter, Mr. Organ and his solicitor were requested to withdraw.

4. Moved by Dr. Alexander Wood, seconded by Dr. A. Smith, and agreed to,_- "That Mr. Organ be recalled, and that the evidence in support of the charges be read in his presence."

Mr. Organ and his solicitor having been recalled, the whole of the evidence in proof of the charges was read.

Mr. Organ was then asked whether he had any answer to offer in refutation of the evidence which had been read. Whereupon Mr. Organ's solicitor declared, on the part of Richard Organ, that he declined to take any part in the proceedings of the Council, relying upon the letter above quoted, which he again read.

$\mathrm{Mr}$. Organ and his solicitor then withdrew.

5. Moved by Sir C. Hastings, seconded by Dr. Alex. Wood, and agreed to, - "That it has been proved to the satisfaction of this Council that the entry of the name of Richard Organ on the Register has been frandulently and incorrectly made."

6. Moved by Dr. Storrar, seconded by Mr. 'Teale, and agreed to,-_" That Richard Organ is judged by this Council, after due inquiry, to have been guilty of infamous conduct in a professional respect."

7. Moved by Dr. Storrar, seconded by Dr. A. Thomson, and agreed to,- "That the further consideration of the case of Richard Organ be adjourned till to-morrow, at two o'clock."

The adjourned debate on the Dublin Apothecaries question, after having been again resumed, was further adjourned on the motion of Dr. Storrar.

It was resolved-"That the Council meet to-morrow, as a Committee on Education, at twelve o'clock." Confirmed-B. C. Brodie.

\section{MINUTES OF MEETING, JUNE 19TH.}

Sir Benjamin C. Brodie, Bart., President, took the chair, at two o'clock P.M.

Present-Dr. Burrows, Mr. Green, Mr. Nussey, Dr. Acland, Dr, Bond, Dr. Embleton, Dr. Storrar, Dr. Alexander Wood, Dr. Andrew Wood, Mr. Watt, Mr. syme, Dr. A. Thomson, Dr. A. Smith, Dr. Leet, Dr. Apjohn, Dr. Corrigan, Sir James Clark, Sir Charles Hastings, Mr. Lawrence, Mr. Teale, Dr. Christison, Dr. Stokes. Dr. Francis Hawkins, Registrar.

The minutes of the last meeting were read and confirmed.

The solicitors of the Council being present-

1. Moved by Mr. Teale, seconded by Dr. Alexander Wood, and agreed to,- "That it having been proved to the satisfaction of the General Council that the entry of the name of Richard Organ has been fraudulently and incorrectly made on the Register, the General Council do by this order, in writing, direct that his name be erased from the Register."

2. Moved by Mr. Green, seconded by Mr. Nussey, and agreed to,- "That Richard Organ, having been judged by this General Council, after due inquiry, to have been guilty of infamous conduct in a professional respect, the General Council do hereby adjudge that the name of the said Richard Organ be erased from the Register, and do by this order direct the Registrar to erase his name from the Reuister accordingly."

3. Moved by Dr. Storrar, seconded by Mr. Syme, and agreed to,-. " That a copy of these orders, signed by the President in the Chair, and countersigned by the Registrar, be transmitted to Richard Organ."

The adjourned debate on the Dublin Apothecaries' question was resumed.

Dr. Alexander Wood was allowed to withdraw the amendment which he had moved on the 16th of June-viz., "That it does not appear to the Medical Council, that the Act of the Apothecaries' Hall of Dublin confers on the licentiates of that body any right to practise medicine;-That in the opinion of the Council, the inclusion of the title of licentiates of that body in Schedule $(\mathrm{A})$ of the Medical Act does not confer any new powers on that body;- That the Council, therefore, adhere to the opininn expressed by them on the 8th of August, 1859," in order that the amendment moved by Dr. Corrigan, on the 18th of June, might be substituted for it-viz., "That the General Medical Council, having again carefully considered the subject referred to in the letter from the War-office, of the 23rd of March, 1560, addressed to the Secretary of the Apothecaries' Hall of Ireland, adhere to the opinion expressed by them in 630 their Resolution of Aug. 9th, 1859, which is as follows:- That it is the opinion of this Council that the licence of the Apothe. caries' Hall of Ireland is not equivalent to a degree or licence in medicine from a university or college authorized to grant such, as from a perusal of the Apothecaries Act, 31 Geo. III. there does not appear to be any provision or authority for examining in medicine: and further, that if a candidate be rejected by the Apothecaries' Hall of Ireland, the Apothecaries Act, sect. 23, declares that the rejected candidate may appeal to the King and Queen's College of Physicians in Ireland, who are then authorized to reverse such decision, if it seem fit to them, and to grant to such appellant the right to practise the art and mystery of an apothecary without any examination in medicine."

The amendment moved by Dr. Corrigan and seconded by Dr. Stokes was put to the vote, and carried.

Dr. Storrar required that the names of the majority and minority should be entered on the minutes.

Majo"ity: Mr. Green, Dr. Acland, Dr. Bond, Dr. Alexander Wood, Dr. And. Wood, Mr. Watt, Dr. A. Smith, Dr. Apjohn Dr. Corrigan, Mr. Lawrence, Mr. Teale, Dr. Stokes. -Minonity. The President, Dr. Burrows, Mr. Nussey, Dr. Embleton, Dr. Storrar, Mr. Syme, Dr. A. Thomson, Dr. Leet, Sir J. Clark, Sir C. Hastings, Dr. Christison.

4. Moved by Dr. Andrew Wood, and seconded by Dr. Christison,-_" "That the letter from Dr. J. Murray Macculloch, and the opinion of counsel on his case, be recorded on the minutes."

Amendment moved by Dr. Corrigan, and seconded by Dr. A. Smith, - "That the letter from Dr. Macculloch be inserted in the minutes."-Amendment carried.

" 38, Castle-street, Dumfries, May 29th, 1860.

"SrR,-A1though personally a stranger to you, I take the liberty of writing to you upon a matter personal to myself. I have observed from a notice, published in the Edinburgh Medical Journal for December, 1859, that it has been proposed to call the attention of the Medical Council, of which you are President, to my connexion with the case of Mr. Broatch, who was convicted under the Medical Act in September last year.

"I am anxious that my conduct should not be misunder. stood; and as I am not aware whether the Council may think it right to take any official cognizance of the matter, I beg to solicit your impartial perusal of the facts, in order that with you, as the head of my profession, I may not stand under undeserved imputation.

"I do not trouble you with any of the personal and acri. monious discussion which has taken place. It may suffice to say that a great deal of enmity and ill feeling has been exhibited towards me, and I have no doubt I have myself been heated, and in some respects injudicious.

"The facts to which I beg your attention are these. The Medical Act, which fixed the date of its operations for the 1st of January, 1859, was not fully understood in the district of the county in which I resided (Dnmfries.) Indeed, the only advertisement on the subject (which appeared only once in one of the local papers of the district), informing medical practitioners of the necessity for registration, was on the date of December 14th, 1858; so that a very short time was given to comply with the provisions of the Act.

"As one of the conditions of the registration, it was necessary to forward certain attestations of qualification, one of which was the signature of a medical man to a certificate pur. porting to state that the claimant had exhibited for the inspection of the signer his diploma or qualification.

"Knowing the object of the statute to be to prevent the operation of quacks and charlatans, under the cloak of professional titles, 1 regarded this as a mere matter of form with respect to medical men on whose qualifications no reasonable doubt rested, and I have reason to know that, it was so re. garded by the majority of the practitioners in this district.

"Mr. Broatch was one of the medical men of this district who did not hear of, or see, the advertisement of the 14th December, 1858, until nearly the entire interval had expired. He came to me a few days before the lst of January, 1859, to sign his certificate. I asked him for his diploma, as the certificate stated that I had seen it. He told me that he had passed, and got his diploma in March, 1822, from the Edinburgh Royal College of Surgeons; that in 1826 , before leaving Edinburgh (where he first practised,) he had brain fever, was long ill and insensible, and that when he recovered, he found he had been robbed, his diploma having disappeared with the other things Shortly afterwards, removing to Dunscore, he commenced practice again, and finding no special use for his diploma, he had neglected to apply for a duplicate or a certificate. 
"I fully believed Mr. Broatch, and, indeed, notwithstanding subsequent events, I still believe that he did not deceive me. I had known Mr. Broatch for thirty years, having repeatedly met him in practice, and ever found him truthful, honourable, and skilful. I knew that he was met and respected by all the practitioners of the aistrict of any standing. I knew he was respected, and bore a high character in his own locality. I knew he was, and had been, parochial surgeon to two parishes for many years-an appointment not held by unqualified practitioners in this part of the country before the passing of the Medical Act. I had seen his name year after year in the "London Medical Directory"-a work of general accuracy-as a Licentiate of the Edinburgh Royal College of Surgeons, 1822; and I knew, from personal experience, that his story was not improbable. I had myself lost one of my diplomas for a long time, and recovered it by the merest chance, and I had experienced the delay and difficulty arising out of an application for a duplicate or certificate, even when my application was supported by the powerful aid of my late friend, Mr. Liston. According to Mr. Broatch's statement, it was simply impossible for him to comply with the letter of the requirement of the certificate, and yet it appeared that in a few days be must either be registered or professionally outlawed. I did not see Mr. Broatch's diploma, but I firmly believed in his qualification; and as I regarded the certificate as intended to supply what the Act calls 'proper evidence that the person claiming registration is entitled to it,' I signed it, professional outlawry being the result in a few days if $I$ had not. I do not seek to justify myself for so doing. It was incautious-an act of the feelings unsanctioned by the judgment and the dictates of self-interest, and I am very willing, and do express my regret. The circum stances you will be able to estimate as strongly as I can.

"I do not wish now to discuss the question of Mr. Broatch's trial. I may only say, that so far from any desire on my part to defeat or assist in defeating the provisions of the Act, I immediately replied to the inquiries of the Registrar of the Scottish (Branch) Council, in perfect frankness, and had also to perform the painful duty of giving my evidence against $\mathrm{Mr}$. Broatch, without which, by the way, he could not have been convicted at all.

"Such are very briefly the facts of the matter referred to in the minute published in the Edinburgh Journal.

" Of the publication of that minute, in so far as it refers to me, I say nothing further than to remark that the Medical Act does not contemplate or authorize such a publication. The status and character of a medical man should not be injured wantonly, and it certainly was not intended that ex parte accusations should be circulated in the public journals under the shield of a minute of the (Branch) Medical Council, more especially before the said Council, by their own showing, knew whether they were entitled to entertain the subject or not; but, as I said before, I do not wish to trouble you with personal grievances or discussion.

"I have been anxious to state to you the circumstances under which I acted; having committed an error, I have desired to express regret. I feel sure you will pardon my intru. sion in such a matter, and beg leave to subscribe myself,

$$
\text { "Your most obedient servant, }
$$

"James MuRRay MoCulloch.

"To Sir Beujamin C. Brodie, Bart., 14, Savile-row, London, W."

5. The following resolution was unanimously adopted by the Council, on the motion of Mr. Green, seconded by Dr. Andrew Wood, " Having just learned that during this day's sitting, Dr. Williams, the representative of the Royal College of Surgeons of Treland, has died, under the unprecedented and afflicting circumstance, the Council record the unfeigned sorrow which they feel under the irreparable loss of a colleague so estimable and distinguished."

Confirmed-B. C. Brodie.

\section{Outrespondence.}

$$
\text { "Audi alteram partem." }
$$

\section{REGISTRATION OF DEATHS (SCOTLAND) BILL.} To the Editor of THE LANCET.

SIR,-I have lately been in communication with the Glasgow Faculty of Medicine, through which body I have been informed of an important movement now progressing in Scotland, and affecting the interests of the profession in that country.
A Bill is now under the consideration of the Honse of Commons to amend the Act 17 and 18 Vict., intituled "An Act to Provide for the Better Registration of Births, Deaths, and Marriages in Scotland," under the 4lst section of which statute medical practitioners are compelled to render important services to the State without remuneration, and for non-obedience of the harsh enactment are liable to serions penalties. The offensive clause is, that "the medical person who shall have been in attendance during the last illness and until the death of any person shall, within fourteen days after the death of such person, and under a penalty not exceeding $40 \mathrm{~s}$. in case of failure, transmit to the registrar a certificate of such death in the form" given.

The corporation which I have named have energetically opposed the arbitrary law, feeling that all attempts to coerce, by Act of Parliament or otherwise, scientific or professional men to give gratuitously the results of their labours for the benefit of society are unjust in principle, baneful to the interests of science, and can end only in failing to effect the object for which they are ostensibly intended.

It has been suggested to me that the medical gentlemen of England might materially assist their neighbours by subscribing a petition to the House of Commons, praying that the clanse quoted be expunged. The Glasgow Faculty of Medicine will give a form of petition, or any gentleman interested in the matter might draw one from the above statement of facts, and submit it for presentation to the member for his place. Perhaps before this letter is published the Bill now before the House may be read, and so the opportunity may be lost. However, the eventilation of our neighbours' complaint will do no harm, and may assist to stir a little sympathy, and excite cooperation and cordial understanding, which can bring about only good to the fraternity of doctors.

I am, Sir, yours most obediently,

Charles-square, June, 1860 EDWARD J. WOOD.

\section{FRENCH HOSPITAL STUDY. \\ To the Editor of THE LANCET.}

SIR,-The interesting remarks of your Parisian correspondent, on the subject of French Hospital Study, deserve the best attention of all who propose taking a "finisher" abroad. The advantages of a residence at any of the great continental schools are so often marred by inexperience and want of due arrangement of time, that the student not unfrequently finds the true benefit of his stay to coincide pretty exactly with the conclusion of his visit. Following, then, in the footsteps of " our own correspondent," permit another "old hand" to add a few notes to what has been already so well begun.

In the first place, let me caution the student against attempting too much. In Paris the facilities for improvement are so extensive that it is, perhaps, a little puzzling sometimes to know what to select; but, doubtless, after a day or two with each of its principal professors, it will not be difficult for each man to select the teacher must after his own heart. If, however, instead of doing this, he has a different hospital for every day in the week, and a constant change of lectures and clinical demonstrations, he will conclude his season with the reflection that he has frittered away his time and secured for his trouble nothing better than dim recollections and halfdigested facts.

The hospitals in Paris which are above all others deserving of his attention, are those devoted to affections of special organs-as diseases of the skin, venereal complaints, and children's disorders, can there be studied on a vast and unrivalled scale. But the value of such study is very much enhanced by the cours particuliers, conducted by the "internes," at rates varying from thirty to fifty francs per month. By means of these excellent private classes, the student is afforded the best opportunity of thoroughly examining each variety of the disease; its leading features are pointed out and explained, and, in course of time, he is himself compelled to delirer his diagnosis on every case. Let him not, then, neglect to attend one or more of such courses, for, in addition to their professional value, the advantages in the way of French conversation which they afford are by no means to be despised.

of course, on first arriving in Paris, a good deal of hospital attendance is lost from the difficulty that every fresh ear experiences in understanding French. But let him not despair; let him work away bravely, casting aside all English books, and taking every opportunity of familiarizing his ear with the unwonted sounds by a steady attendance upon the lectures of the Faculty of Medicine. And he will find that, by boarding 631 